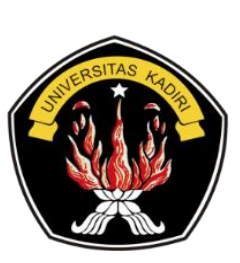

Tersedia secara online di http://ojs.unik-kediri.ac.id/index.php/jatiunik/issue/view/76

\title{
Analisis Bahaya Covid-19 Sebagai Upaya Pencegahan Penyebaran Di Fasilitas Umum Bandara Dengan Metode Hazard Identification Risk Assessment (HIRA)
}

\author{
Rizkia Ainun $A^{* 1}$, Tri Sulistiyani $\mathbf{M}^{2}$, Defry Ananto ${ }^{3}$, Muthia Ranti ${ }^{4}$, Riska Miranda $\mathbf{G}^{5}$, Gina \\ Putri ${ }^{6}$, Salafuddin ${ }^{7}$ \\ 1,2,3,4,5,6,7 Program Studi Teknik Kimia, Institut Teknologi Nasional Bandung \\ Email :rantimuthia12345@gmail.com
}

\begin{tabular}{|c|c|}
\hline InformasiArtikel & $A b s t r a c t$ \\
\hline $\begin{array}{l}\text { Riwayat Artikel : } \\
\text { Received : } 23-\text { Juli }-2020 \\
\text { Revised : } 9-\text { Oktober }-2020 \\
\text { Accepted : } 16 \text { - Oktober }-2020\end{array}$ & $\begin{array}{l}\text { The Covid-19 pandemic is endemic throughout the world, } \\
\text { especially in Indonesia. One of the effects of the covid-19 } \\
\text { pandemic was the flight system at the airport which was later } \\
\text { shut down. Some of them cause some losses from this incident. } \\
\text { To deal with the New Normal situation, therefore OHS risk } \\
\text { management is an effort to manage OHS risk to reduce Covid-19 }\end{array}$ \\
\hline $\begin{array}{l}\text { Kata kunci: } \\
\text { Airport } \\
\text { Covid-19 } \\
\text { Danger } \\
\text { HIRARC }\end{array}$ & $\begin{array}{l}\text { virus transmission. This study is to determine hazard } \\
\text { identification, risk assessment, and risk control with the Danger } \\
\text { Identification, Risk Assessment and Risk Control (HIRARC) } \\
\text { methods at the Airport. The research method used is descriptive } \\
\text { research that is the result of data research, in the form of } \\
\text { research journals and online media. The object of research is the } \\
\text { activity that has the potential danger of co-19 virus transmission } \\
\text { at the airport. The results of the study can be seen that the } \\
\text { activities at the airport there are } 12 \text { main activities, Among them } \\
\text { are } 3 \text { extreme risk category activities, } 5 \text { high risk category, and } 4 \\
\text { medium risk category. The proposed COVID-19 } \\
\text { countermeasures are limiting flight quotas at the airport, } \\
\text { providing hygiene kits according to recommended health } \\
\text { protocols and Personal Protective Equipment. }\end{array}$ \\
\hline
\end{tabular}

Untuk melakukan sitasi pada penelitian ini dengan format :

N. Chartres, L. A. Bero, and S. L. Norris, "A review of methods used for hazard identification and risk assessment of environmental hazards," Environ. Int., vol. 123, no. December 2018, pp. 231239, 2019.

\begin{abstract}
A b s trak
Pandemi Covid-19 sedang mewabah di seluruh dunia, terutama di Indonesia. Salah satu dampak dari pandemi covid-19 ini adalah system penerbangan di bandara yang belakangan sempat ditutup. Beberapa diantaranya menyebabkan beberapa kerugian dari kejadian ini. Untuk menghadapi keadaan New Normal, maka dari itu manajemen risiko K3 merupakan salah satu upaya untuk mengelola risiko $\mathrm{K} 3$ untuk mengurangi penularan virus Covid19. Pada penelitian ini adalah untuk mengetahui identifikasi bahaya, penilaian risiko, dan pengendalian risiko dengan metode Hazard Identification, Risk Assessment And Risk Control (HIRARC) di Bandara. Metode penelitian yang digunakan adalah penelitian deskriptif yaitu Hasil riset data, berupa Jurnal-jurnal penelitian dan Media online. Objek penelitian adalah kegiatan yang berpotensi bahaya penularan virus covid-19 di Bandara.
\end{abstract}


Hasil penelitian dapat diketahui bahwa pada kegiatan-kegiatan di bandara terdapat 12 kegiatan utama, Di antaranya 3 kegiatan kategori risiko ekstrem, 5 kegiatan kategori risiko tinggi, dan 4 kegiatan kategori resiko sedang. Upaya penanggulangan COVID-19 yang diusulkan adalah melakukan pembatasan kuota penerbangan di bandara, penyediaan peralatan kebersihan sesuai protokol kesehatan yang dianjurkan dan perlengkapan Alat Pelindung Diri.

\section{Pendahuluan}

Diawal tahun 2020, dunia digemparkan dengan merebaknya virus baru yaitu coronavirus jenis baru (SARS-CoV-2) dan penyakitnya disebut Coronavirus disease 2019 (COVID-19) [1]. Virus Covid-19 atau corona merupakan virus yang menyerang saluran pernafasan atas yang menimbulkan gejala seperti flu, batuk dan demam. Virus ini merupakan virus yang dapat menular dimana penularannya dapat melalui droplet atau cairan dalam tubuh penderitanya. Proses penyembuhan virus ini juga cukup memakan waktu yang lama berkisar 14 hari [2], [3]. Diketahui virus ini berasal dari Wuhan, Tiongkok, China. Ditemukan virus ini pada akhir Desember tahun 2019 [4]. Kemudian sampai saat ini sudah dipastikan terdapat 65 negara yang telah terjangkit virus saat ini.

Pada Indonesia sendiri pemerintahan telah mengeluarkan tentang perihal darurat bencana COVID-19 terhitung mulai tanggal 29 Februari 2020 hingga 29 Mei 2020. Dimana langkah yang telah dilakukan oleh pemerintah untuk dapat menyelesaikan kasus virus ini, salah satunya adalah dengan mensosialisasikan atau menerapkan gerakan Social Distancing. Konsep ini dijelaskan bahwa untuk dapat mengurangi bahkan memutus mata rantai infeksi COVID-19 seseorang harus dilakukan antara lain menjaga jarak aman antar manusia minimal 2 meter, dan tidak melakukan kontak langsung dengan orang lain, dan menghindari pertemuan massal di tempat keramaian [5], [6].

Penyebaran virus corona dapat terjadi dimanapun salah satunya yaitu di bandara. Penyebaran virus corona di bandara terbilang cukup tinggi mengingat bandara merupakan tempat yang tidak pernah sepi penumpang sehingga social distancing sulit dilakukan di tempat ini. Penyebaran virus tersebut dapat terjadi contohnya pada saat penumpang berada di ruang tunggu, maupun pada saat berada di dalam pesawat [7]. Penumpang yang tanpa sadar telah terinfeksi corona merupakan orang-orang yang berpotensi tinggi dalam menyebarkan virus ini. Oleh karena itu untuk mengantisipasi masalah ini, International Health Regulation/IHR melakukan kegiatan karantina, pemeriksaan alat angkut, pengendalian vektor serta tindakan penyehatan. Hal yang dilaksanakan melalui pengawasan alat angkut barang, orang sekitar, barang bawaan, dan lingkungan yang datang dari wilayah/negara terjangkit COVID-19 yang dilaksanakan oleh pihak bandara dalam kesiapan menghadapi ancaman COVID-19 maupun penyakit lainnya.

Berdasarkan pemaran diatas, maka penting untuk mengidentifikasi seberapa besar bahaya penyebaran COVID-19 di bandara, kemudian melakukan penilaian risiko dari bahaya tersebut lalu membuat program pengendalian bahaya tersebut agar dapat diminimalisir tingkat risikonya ke yang lebih rendah dengan tujuan mencegah terjadinya penyebaran COVID-19 di bandara [8]. 


\section{Tinjauan Pustaka}

\subsection{HIRA}

Hazard Identification and Risk Assessment (HIRA) yaitu suatu metode atau teknik untuk mengidentifikasi potensi bahaya kerja dengan mendefinisikan karakteristik bahaya yang mungkin terjadi dan mengevaluasi risiko yang terjadi melalui penilaian risiko dengan menggunakan matriks penilaian risiko [9], [10]. Risiko secara umum dapat dikaitkan dengan kemungkinan atau probabilitas terjadinya peristiwa diluar yang diharapkan. Risiko juga dapat diartikan sebagai perpaduan antara probabilitas dan tingkat keparahan kerusakan atau kerugian. Risiko adalah kesempatan untuk merugi (Risk is hance of loss) yaitu dipergunakan untuk menunjukkan suatu keadaan dimana terdapat suatu keterbukaan terhadapi kerugian atau suatu kemungkinan kerugian [11], [12]. Risiko adalah kemungkinan kerugian (Risk of the possibility of loss) yaitu probabilitas suatu peristiwa berada diantara nol dan satu [13], [14]. Risiko adalah ketidakpastian (Risk is uncertainty) berarti bahwa risiko berhubungan dengan ketidakpastian [15], [16]. Dalam hal ini juga diperlukan manajemen risiko sebagai upaya mengatur timbulnya risiko yang ada [17]. Manajemen risiko adalah semua tahapan pekerjaan yang berhubungan dengan risiko, diantaranya yaitu penilaian (assessment), perencanaan (planning), pengendalian (handling) dan pemantauan (monitoring) kecelakaan [18], [19]. Terkait dengan Hazard atau bahaya merupakan sumber, situasi atau tindakan yang berpotensi menciderai manusia atau kondisi kelainan fisik atau mental yang teridentifikasi berasal dari dan atau bertambah buruk karena kegiatan kerja atau situasi yang terkait dengan pekerjaan [20], [21].

\section{Metode Penelitian}

Metode penelitian yang digunakan adalah penelitian deskriptif [22]. Hasil penelitian ini merupakan hasil riset data melalui daring (Online) berdasarkan pengumpulan data dan jurnal-jurnal penelitian, pengamatan kegiatan-kegiatan beresiko yang bertujuan menjelaskan nilai dari risiko yang terdapat di setiap area kerja dengan diskusi kelompok untuk proses analisa keselamatan kerja dengan menentukan tingkat likehood dan severity dari setiap risiko, dan penulisan jurnal ilmiah [23]. Objek penelitian yang diambil adalah kegiatan yang biasa dilakukan di Bandara yaitu segala bentuk kegitatan yang berpotensi bahaya dan berisiko dalam penularan virus covid-19.

\section{Hasil dan Pembahasan}

Tabel 1. Pengendalian Risiko

\begin{tabular}{|c|c|c|c|c|c|c|c|c|c|}
\hline \multirow[t]{2}{*}{ No. } & \multirow[t]{2}{*}{ Temuan } & \multirow[t]{2}{*}{ Risiko } & \multirow[t]{2}{*}{ Sumber } & \multirow{2}{*}{$\begin{array}{l}\text { Jenis } \\
\text { Bahaya }\end{array}$} & \multicolumn{4}{|c|}{ Evaluasi Risiko } & \multirow[t]{2}{*}{ Pengendalian } \\
\hline & & & & & $\begin{array}{l}\text { Kons } \\
\text { ek- } \\
\text { uensi }\end{array}$ & $\begin{array}{l}\text { Kemung } \\
\text { kinan } \\
\text { Terjadi }\end{array}$ & Nilai & Kategori & \\
\hline 1 & $\begin{array}{l}\text { Ruang } \\
\text { tunggu }\end{array}$ & $\begin{array}{l}\text { Bersentuhan } \\
\text { tanpa } \\
\text { sengaja pada } \\
\text { kursi yang } \\
\text { sudah } \\
\text { terpapar } \\
\text { virus }\end{array}$ & $\begin{array}{l}\text { Duduk } \\
\text { diruang } \\
\text { tunggu }\end{array}$ & $\begin{array}{l}\text { Terinfeksi } \\
\text { virus }\end{array}$ & 3 & $\mathrm{~A}$ & $3 \mathrm{~A}$ & Ekstrim & $\begin{array}{lr}\text { Pemberian jarak } \\
\text { antar kursi dan } \\
\text { penumpang }\end{array}$ \\
\hline 2 & $\begin{array}{l}\text { Kegiatan cek } \\
\text { suhu tubuh }\end{array}$ & $\begin{array}{l}\text { Berdekatan } \\
\text { dengan } \\
\text { orang lain, } \\
\text { karena tidak }\end{array}$ & $\begin{array}{l}\text { Kegiatan } \\
\text { petugas } \\
\text { pengecekan } \\
\text { antar }\end{array}$ & $\begin{array}{l}\text { Terinfeksi } \\
\text { virus }\end{array}$ & 2 & $\mathrm{C}$ & $2 \mathrm{C}$ & Sedang & \begin{tabular}{lr}
\multicolumn{2}{l}{ Menggunakan } \\
APD & terutama \\
masker & serta \\
sarung & tangan,
\end{tabular} \\
\hline
\end{tabular}




\begin{tabular}{|c|c|c|c|c|c|c|c|c|c|}
\hline & & ada jarak & $\begin{array}{l}\text { penumpang } \\
\text { saling } \\
\text { berdekatan }\end{array}$ & & & & & & $\begin{array}{ll}\text { dan } & \text { selalu } \\
\text { melakukan } & \text { social } \\
\text { distancing } & \\
\end{array}$ \\
\hline 3 & $\begin{array}{l}\text { Check-in } \\
\text { pesawat }\end{array}$ & $\begin{array}{l}\text { Bersentuhan } \\
\text { dengan } \\
\text { orang lain } \\
\text { tanpa } \\
\text { sengaja }\end{array}$ & $\begin{array}{l}\text { Kontak } \\
\text { langsung } \\
\text { saat } \\
\text { menunjukka } \\
\mathrm{n} \quad \text { kartu } \\
\text { identitas } \\
\end{array}$ & $\begin{array}{l}\text { Terinfeksi } \\
\text { virus }\end{array}$ & 2 & D & $2 \mathrm{D}$ & Sedang & \begin{tabular}{lr}
\multicolumn{2}{l}{ Menggunakan } \\
APD $\quad$ terutama \\
masker r dan \\
melakukan & social \\
discanting &
\end{tabular} \\
\hline 4 & Bagasi & $\begin{array}{l}\text { Terpapar } \\
\text { virus dari } \\
\text { barang orang } \\
\text { lain }\end{array}$ & $\begin{array}{l}\text { Tidak } \\
\text { dibersihkan } \\
\text { terlebih } \\
\text { dahulu }\end{array}$ & $\begin{array}{l}\text { Terinfeksi } \\
\text { virus }\end{array}$ & 2 & $\mathrm{D}$ & $2 \mathrm{D}$ & Sedang & $\begin{array}{l}\text { Membersihkan } \\
\text { terlebih dahulu } \\
\text { barang yang akan } \\
\text { diambil dari } \\
\text { bagasi, dan tidak } \\
\text { menggunakan jasa } \\
\text { untuk mengambil } \\
\text { barang }\end{array}$ \\
\hline 5 & Troli & $\begin{array}{l}\text { Menyentuh } \\
\text { atau } \\
\text { memegang } \\
\text { troli yang } \\
\text { telah } \\
\text { digunakan } \\
\text { orang lain }\end{array}$ & Kurang steril & $\begin{array}{l}\text { Terinfeksi } \\
\text { virus }\end{array}$ & 3 & A & $3 \mathrm{~A}$ & ekstrim & $\begin{array}{l}\text { Menggunakan } \\
\text { APD atau } \\
\text { membersihkan } \\
\text { terlebih dahulu } \\
\text { sebelum } \\
\text { menggunakan } \\
\text { troli, } \\
\text { melakukan dan } \\
\text { pembersihan atau } \\
\text { penyemprotan } \\
\text { desinfektan secara } \\
\text { berkala } \\
\end{array}$ \\
\hline 6 & $\begin{array}{l}\text { Escalator di } \\
\text { bandara }\end{array}$ & $\begin{array}{l}\text { Menyentuh } \\
\text { pegangan } \\
\text { tangan } \\
\text { tangga atau } \\
\text { escalator } \\
\text { yang tidak } \\
\text { steril atau } \\
\text { bekas dari } \\
\text { pegangan } \\
\text { orang yang } \\
\text { positif virus }\end{array}$ & $\begin{array}{l}\text { Kegiatan } \\
\text { orang orang } \\
\text { melewati } \\
\text { escalator di } \\
\text { bandara dan } \\
\text { tidak adanya } \\
\text { jarak antar } \\
\text { pengguna } \\
\text { escalator }\end{array}$ & $\begin{array}{l}\text { Terinfeksi } \\
\text { virus }\end{array}$ & 2 & B & $2 \mathrm{~B}$ & Tinggi & $\begin{array}{l}\text { Adanya jarak } \\
\text { antar penumpang } \\
\text { yang } \\
\text { mengguanakn } \\
\text { escalator dan } \\
\text { pembersiohan } \\
\text { pegangan pada } \\
\text { escalator secara } \\
\text { berkala }\end{array}$ \\
\hline 7 & $\begin{array}{ll}\text { Tempat } & \\
\text { duduk } \\
\text { pesawat }\end{array}$ & $\begin{array}{l}\text { Menyentuh } \\
\text { atau } \\
\text { berdekatan } \\
\text { dengan } \\
\text { orang lain, } \\
\text { karena tidak } \\
\text { ad nya jarak }\end{array}$ & $\begin{array}{l}\text { Duduk di } \\
\text { kusri dalam } \\
\text { pesawat } \\
\text { tanpa adanya } \\
\text { jarak }\end{array}$ & $\begin{array}{l}\text { Terinfeksi } \\
\text { virus } \\
\text { corona }\end{array}$ & 3 & A & $3 \mathrm{~A}$ & Ekstrim & $\begin{array}{l}\text { Adanya jarak dari } \\
\text { kursi ke kursi yag } \\
\text { lain, pengguanaan } \\
\text { APD bagi } \\
\text { penumpang dan } \\
\text { lakukan } \\
\text { pembersihan } \\
\text { secara berkala }\end{array}$ \\
\hline 8 & \begin{tabular}{ll}
\multicolumn{2}{l}{ Penggunaan } \\
toilet & di \\
bandara & \\
maupun & di \\
pesawat &
\end{tabular} & $\begin{array}{l}\text { Menyentuh } \\
\text { pintu atau } \\
\text { alat-alat } \\
\text { yang ada } \\
\text { dalam toilet }\end{array}$ & $\begin{array}{l}\text { Tidak } \\
\text { membersihk } \\
\text { an atau } \\
\text { menyetuh } \\
\text { langsung } \\
\text { alat atau } \\
\text { pintu toliet }\end{array}$ & $\begin{array}{l}\text { Terinfeksi } \\
\text { virus } \\
\text { corona }\end{array}$ & 2 & B & $2 \mathrm{~B}$ & Tinggi & $\begin{array}{l}\text { Pembersihan } \\
\text { toilet secara } \\
\text { berkala, membuka } \\
\text { pintu dengan siku. } \\
\text { Dan pengguna } \\
\text { toilet } \\
\text { menggunakan } \\
\text { APD dengan } \\
\text { cairan ozone- } \\
\text { infused }\end{array}$ \\
\hline
\end{tabular}




\begin{tabular}{|c|c|c|c|c|c|c|c|c|c|}
\hline 9 & $\begin{array}{l}\text { Tempat } \\
\text { makan/ } \\
\text { foodcourt }\end{array}$ & $\begin{array}{l}\text { Bersentuhan } \\
\text { dengan } \\
\text { orang lain } \\
\text { yang positif } \\
\text { corona tanpa } \\
\text { sengaja }\end{array}$ & $\begin{array}{l}\text { Bersentuhan } \\
\text { atau } \\
\text { berdekatan } \\
\text { dengan } \\
\text { orang lain } \\
\text { saat } \\
\text { pemesanan } \\
\text { makanan } \\
\text { atau tempat } \\
\text { duduk tidak } \\
\text { adanya jarak } \\
\text { antar } \\
\text { pembeli, } \\
\text { tidak } \\
\text { mencuci } \\
\text { tangann } \\
\text { sebelum } \\
\text { makan }\end{array}$ & $\begin{array}{l}\text { Terinfeksi } \\
\text { virus } \\
\text { corona }\end{array}$ & 3 & C & $3 \mathrm{C}$ & Tinggi & $\begin{array}{l}\text { Jaga jarak dengan } \\
\text { pembeli lain saat } \\
\text { pemesanan } \\
\text { makanan, jaga } \\
\text { jarak tempat } \\
\text { duduk saat } \\
\text { makan, dan } \\
\text { mencuci tangan } \\
\text { dengan sabun/ } \\
\text { handsanitizer } \\
\text { sebelum makan }\end{array}$ \\
\hline 10 & $\begin{array}{l}\text { Posko } \\
\text { Pemeriksaan } \\
\text { Dokumen } \\
\text { Perjalanan }\end{array}$ & $\begin{array}{l}\text { Bersentuhan } \\
\text { dengan } \\
\text { orang lain } \\
\text { tanpa } \\
\text { disengaja } \\
\text { dengan jarak } \\
\text { yang cukup } \\
\text { dekat }\end{array}$ & $\begin{array}{l}\text { Mengantri } \\
\text { panjang } \\
\text { tanpa adanya } \\
\text { physical } \\
\text { distancing }\end{array}$ & $\begin{array}{l}\text { Terinfeksi } \\
\text { virus } \\
\text { corona }\end{array}$ & 2 & B & $2 \mathrm{~B}$ & Sedang & $\begin{array}{l}\text { Pemberian jarak } \\
\text { pada lantai dan } \\
\text { perbanyak posko } \\
\text { pemeriksaan } \\
\text { dokumen } \\
\text { perjalanan, serta } \\
\text { pemerintah } \\
\text { melakukan } \\
\text { pembatasan kuota } \\
\text { penerbangan }\end{array}$ \\
\hline 11 & $\begin{array}{l}\text { Boarding } \\
\text { saat masuk } \\
\text { pesawat }\end{array}$ & $\begin{array}{l}\text { Bersentuhan } \\
\text { dengan } \\
\text { orang lain } \\
\text { yang positif } \\
\text { corona tanpa } \\
\text { sengaja }\end{array}$ & $\begin{array}{l}\text { Antrian } \\
\text { tanpa ada } \\
\text { jarak antar } \\
\text { penumpang } \\
\text { saat masuk } \\
\text { kedalam } \\
\text { pesawat }\end{array}$ & $\begin{array}{l}\text { Terinfeksi } \\
\text { virus } \\
\text { corona }\end{array}$ & 3 & C & $3 \mathrm{C}$ & Tinggi & $\begin{array}{l}\text { Antrian saat } \\
\text { masuk pesawat } \\
\text { dilakukan dengan } \\
\text { adanya jarak antar } \\
\text { penumpang } \\
\text { minimal } 1 \text { meter } \\
\text { untuk } \\
\text { menghindari } \\
\text { kontak langsung } \\
\text { antar penumpan, } \\
\text { penggunaan } \\
\text { masker dan } \\
\text { pengecekan suhu } \\
\text { tubuh kembali } \\
\text { saat boarding } \\
\text { pesawat }\end{array}$ \\
\hline 12 & $\begin{array}{l}\text { Orang tanpa } \\
\text { gejala }\end{array}$ & $\begin{array}{l}\text { Bersentuhan } \\
\text { dengan } \\
\text { orang lain } \\
\text { yang positif } \\
\text { corona tanpa } \\
\text { sengaja }\end{array}$ & $\begin{array}{l}\text { Bersentuhan } \\
\text { atau } \\
\text { berdekatan } \\
\text { dengan } \\
\text { orang lain } \\
\text { tanpa } \\
\text { sengaja saat } \\
\text { masuk } \\
\text { pesawat atau } \\
\text { saat sedang } \\
\text { perjalanan } \\
\text { ke bandara. }\end{array}$ & $\begin{array}{l}\text { Terinfeksi } \\
\text { virus } \\
\text { corona }\end{array}$ & 3 & C & $3 \mathrm{C}$ & Tinggi & $\begin{array}{l}\text { Staff dan Crew } \\
\text { Pesawat wajib } \\
\text { menggunakan } \\
\text { APD baik itu } \\
\text { hazmat ataupun } \\
\text { faceshield ketika } \\
\text { sedang bekerja } \\
\text { ditakutkan adanya } \\
\text { orang tanpa gejala }\end{array}$ \\
\hline
\end{tabular}




\begin{tabular}{|c|c|c|c|}
\hline Description & Category & Score & Mishap Definition \\
\hline Catastrophic & I & 4 & Kematian atau kehilangan sistem \\
\hline \multirow{3}{*}{ Critical } & \multirow{3}{*}{ II } & \multirow{3}{*}{3} & Luka berat yang menyebabkan cacat permanen \\
\hline & & & Penyakit akibat kerja yang parah \\
\hline & & & Kerusakan sistem yang berat \\
\hline \multirow{3}{*}{ Marginal } & \multirow{3}{*}{ III } & \multirow{3}{*}{2} & Luka sedang, hanya membutuhkan perawatan medis \\
\hline & & & Penyakit akibat kerja yang ringan \\
\hline & & & Kerusakaan sebagian sistem \\
\hline \multirow{2}{*}{ Neglicable } & \multirow{2}{*}{ IV } & \multirow{2}{*}{1} & Luka ringan yang hanya membutuhkan pertolongan pertama \\
\hline & & & Kerusakan sebagian kecil sistem \\
\hline
\end{tabular}

Gambar 1. Klasifikasi Tingkat Keparahan Bahaya

Sumber : [24]

\begin{tabular}{|c|c|c|l|}
\hline Description & Level & Score & \multicolumn{1}{c|}{ Specific Individual Item } \\
\hline Frequent & $\mathrm{A}$ & 5 & Sering terjadi, berulang kali dalam sistem \\
\hline Probabie & $\mathrm{B}$ & 4 & Terjadi beberapa kali dalam siklus sistem \\
\hline Occasional & $\mathrm{C}$ & 3 & Terjadi kadang-kadang dalam siklus sistem \\
\hline Remote & $\mathrm{D}$ & 2 & Tidak pernah terjadi, tetapi mungkin terjadi dalam siklus sistem \\
\hline Improbable & $\mathrm{E}$ & 1 & $\begin{array}{l}\text { Tidak mungkin, dapat diasumsikan tidak akan pernah terjadi dalam } \\
\text { sistem }\end{array}$ \\
\hline
\end{tabular}

Gambar 2. Klarifikasi Frekuensi Paparan Bahaya

Sumber : [24]

\begin{tabular}{|l|l|l|l|l|l|l|}
\hline \multicolumn{7}{|c|}{ Tingkat Bahaya (Risk Level) } \\
\hline \multirow{2}{*}{} & 5 & 5 & 10 & 15 & 20 & 25 \\
\cline { 2 - 7 } & 4 & 4 & 8 & 12 & 16 & 20 \\
\cline { 2 - 7 } & 3 & 3 & 6 & 9 & 12 & 15 \\
\cline { 2 - 7 } & 2 & 2 & 4 & 6 & 8 & 10 \\
\cline { 2 - 7 } & 1 & 1 & 2 & 3 & 4 & 5 \\
\hline \multirow{2}{*}{ Skala } & 1 & 2 & 3 & 4 & 5 \\
\cline { 2 - 7 } & \multicolumn{5}{|c|}{ Keseriusan (Severity/Consecuences) } \\
\hline
\end{tabular}

Gambar 3. Kriteria Consequence

Sumber : [24]

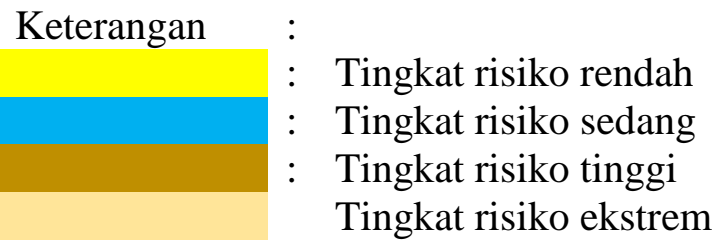

Tabel 2. Kriteria Likelyhood

\begin{tabular}{llll}
\hline & & \multicolumn{2}{c}{ Likelihood } \\
\hline \multirow{2}{*}{ Level Criteria } & Description \\
\cline { 3 - 4 } & & Kualitatif & Kuantitatif \\
\hline
\end{tabular}

1. Jarang terjadi Dapat dipikirkan tetapi tidak hanya saat Kurang dari 1 kali per 10 keadaan yang ekstrim tahun 


\begin{tabular}{cccc}
\hline 2. & $\begin{array}{c}\text { Kemungkinan } \\
\text { kecil }\end{array}$ & $\begin{array}{c}\text { Belum terjadi tetapi bias muncul/terjadi } \\
\text { pada suatu waktu }\end{array}$ & Terjadi 1 kali per 10 tahun \\
\hline 3. & Mungkin & $\begin{array}{c}\text { Seharusnya terjadi dan mungkin telah } \\
\text { terjadi/muncul disini atau di tempat lain }\end{array}$ & $\begin{array}{c}\text { 1 kali per } 5 \text { tahun sampai } \\
\text { 1 kali pertahun }\end{array}$ \\
\hline 4. & $\begin{array}{c}\text { Kemungkinan } \\
\text { besar }\end{array}$ & $\begin{array}{c}\text { Dapat terjadi dengan mudah mungkin } \\
\text { muncul dalam keadaan yang paling } \\
\text { banyak terjadi }\end{array}$ & $\begin{array}{c}\text { Lebih dari } 1 \text { kali per tahun } \\
\text { hingga } 1 \text { kali per bulan }\end{array}$ \\
\hline 5. & Hampir pasti & $\begin{array}{c}\text { Sering terjadi, diharapkan muncul dalam } \\
\text { keadaan yang paling banyak terjadi }\end{array}$ & Lebih dari 1 kali per bulan \\
\hline
\end{tabular}

Sumber : [24]

Tabel 3. Consequences/Severity Consequences/Severity

\begin{tabular}{|c|c|c|c|}
\hline \multicolumn{4}{|c|}{ Consequences/Severity } \\
\hline Level & Uraian & Keparahan Cidera & Hari Kerja \\
\hline 1. & $\begin{array}{c}\text { Tidak } \\
\text { signifikan }\end{array}$ & $\begin{array}{l}\text { Kejadian tidak menimbulkan } \\
\text { kerugian atau cedera pada manusia }\end{array}$ & $\begin{array}{l}\text { Tidak menyebabkan kehilangan } \\
\text { hari kerja }\end{array}$ \\
\hline 2. & Kecil & $\begin{array}{lrr}\text { Menimbulkan cedera ringan } \\
\text { kerugian kecil dan tidak } \\
\text { menimbulkan dampak serius } \\
\text { terhadap kelangsungan bisnis }\end{array}$ & $\begin{array}{l}\text { Masih dapat bekerja pada } \\
\text { hari/shift yang sama }\end{array}$ \\
\hline 3. & Sedang & $\begin{array}{l}\text { Cedera berat dan dirawat dirumah } \\
\text { sakit, tidak menimbulkan cacat } \\
\text { tetap, kerugian financial sedang. }\end{array}$ & $\begin{array}{l}\text { Kehilangan hari kerja dibawah } \\
3 \text { hari }\end{array}$ \\
\hline 4. & Berat & $\begin{array}{l}\text { Menimbulkan cedera parah dan } \\
\text { cacat tetap dan kerugian financial } \\
\text { besar serta menimbulkan dampak } \\
\text { serius terhadap kelangs ungan } \\
\text { usaha }\end{array}$ & $\begin{array}{l}\text { Kehilangan hari kerja } 3 \text { hari } \\
\text { atau lebih }\end{array}$ \\
\hline 5. & Bencana & $\begin{array}{l}\text { Mengakibatkan korban meninggal } \\
\text { dan kerugian parah bahkan dapat } \\
\text { menghentikan kegiatan usaha } \\
\text { selamanya }\end{array}$ & $\begin{array}{l}\text { Kehilangan } \\
\text { selamanya }\end{array}$ \\
\hline
\end{tabular}

Sumber : [24]

Tabel 4. Pengendalian Risiko

\begin{tabular}{|c|c|c|c|}
\hline No & Jenis Kegiatan & $\begin{array}{l}\text { Keterengan } \\
\text { Penilaian }\end{array}$ & Risk Control \\
\hline 1 & $\begin{array}{l}\text { Ruang tunggu } \\
\text { bandara }\end{array}$ & Tinggi & $\begin{array}{l}\text { Membuat tanda jarak pada kursi untuk penerapan } \\
\text { physical distancing } \\
\text { Para penumpang menggunakan masker dan tidak } \\
\text { melakukan interaksi sosial. } \\
\text { Penyediaan hand sanitizer dan sabun cuci tangan di } \\
\text { setiap sudut. }\end{array}$ \\
\hline 2 & $\begin{array}{l}\text { Kegiatan cek } \\
\text { suhu tubuh }\end{array}$ & Sedang & $\begin{array}{l}\text { Petugas menggunakan APD lengkap terdiri dari } \\
\text { masker, sarung tangan karet, face shield, google dan } \\
\text { jas hazmat. } \\
\text { Penyediaan APD untuk petugas terdiri dari masker, } \\
\text { sarung tangan karet dan jas hazmat. Pensterilan alat } \\
\text { dilakukan dengan baik. Alat medis dapat di sterilkan } \\
\text { dengan autoclave pada } \mathrm{P}=1,5 \text { atm } \mathrm{T}=121^{\circ} \mathrm{C} \text { selama } \\
10-12 \text { menit. }\end{array}$ \\
\hline
\end{tabular}




\begin{tabular}{|c|c|c|c|}
\hline & & & $\begin{array}{l}\text { Penerapan social distancing antara petugas dan } \\
\text { penumpang serta penggunaan masker untuk } \\
\text { penumpang sendiri. } \\
\text { Jika ada penumpang yang suhunya lebih dari } 38^{\circ} \mathrm{C} \\
\text { langsung di evakuasi d ruang isolasi yang telah di } \\
\text { sediakan. }\end{array}$ \\
\hline 3 & $\begin{array}{l}\text { Kegiatan } \\
\text { melakukan } \\
\text { check-in } \\
\text { pesawat }\end{array}$ & Sedang & $\begin{array}{l}\text { Penerapan social distancing antara petugas dan } \\
\text { penumpang serta penggunaan masker untuk petugas } \\
\text { dan penumpang. } \\
\text { Petugas mengecek ulang suhu tubuh penumpang. } \\
\text { Bandara memfasilitasi pengecekan suhu dengan } \\
\text { monitor. }\end{array}$ \\
\hline 4 & Bagasi & Sedang & Penyemprotan disenfektan skala berkala \\
\hline 5 & Troli & Sedang & $\begin{array}{l}\text { Pada pegangan troli dilapisi oleh plastik khusus } \\
\text { terlebih dahulu. } \\
\text { Penyemprotan berkala pada troli. }\end{array}$ \\
\hline 6 & $\begin{array}{l}\text { Escalator di } \\
\text { bandara }\end{array}$ & Sedang & $\begin{array}{l}\text { Membuat tanda jarak pada escalator untuk penerapan } \\
\text { physical distancing } \\
\text { Para penumpang menggunakan masker dan tidak } \\
\text { melakukan interaksi sosial. } \\
\text { Penyediaan hand sanitizer dan sabun cuci tangan di } \\
\text { setiap sudut. } \\
\text { Pembersihan escalator secara berkala. }\end{array}$ \\
\hline 7 & $\begin{array}{l}\text { Tempat duduk } \\
\text { dipesawat }\end{array}$ & Tinggi & $\begin{array}{l}\text { Membuat tanda jarak pada kursi penumpang untuk } \\
\text { penerapan physical distancing }\end{array}$ \\
\hline 8 & $\begin{array}{l}\text { Penggunaan } \\
\text { toilet di bandara } \\
\text { maupun } \\
\text { dipesawat }\end{array}$ & Tinggi & $\begin{array}{l}\text { Petugas kebersihan bandara harus menggunakan } \\
\text { APD lengkap. } \\
\text { Penyemprotan disenfektan secara berkala. } \\
\text { Peyediaan handsanitizer disetiap sudut } \\
\text { Tidak boleh menunggu di dalam ruangan toilet. }\end{array}$ \\
\hline 9 & $\begin{array}{c}\text { Tempat } \\
\text { makan/foodcourt }\end{array}$ & Tinggi & $\begin{array}{l}\text { Para penumpang tidak diperbolehkan makan } \\
\text { ditempat dan lebih dibolehkan untuk take away. }\end{array}$ \\
\hline 10 & $\begin{array}{l}\text { Posko } \\
\text { Pemeriksaan } \\
\text { Dokumen } \\
\text { Perjalanan }\end{array}$ & Tinggi & $\begin{array}{l}\text { Penerapan social \& physical distancing antara } \\
\text { petugas dan penumpang serta penggunaan masker } \\
\text { untuk petugas dan penumpang. } \\
\text { melakukan social distancing untuk para penumpang } \\
\text { yang mengantri. } \\
\text { Penambahan tempat dan personil untuk pemeriksaan } \\
\text { dokumen perjalanan. } \\
\text { Pembuatan alur pemeriksaan khusus untuk ibu hamil } \\
\text { atau Usia }>50 \text { thn. }\end{array}$ \\
\hline 11 & $\begin{array}{l}\text { Boarding saat } \\
\text { masuk pesawat }\end{array}$ & Tinggi & $\begin{array}{l}\text { Membuat jarak kurang lebih } 1 \text { meter saat antrian } \\
\text { masuk pesawat } \\
\text { Membuat antrian nomor kursi saat boarding misalnya } \\
\text { dengan nomor kursi terkecil terlebih dahulu }\end{array}$ \\
\hline 12 & $\begin{array}{l}\text { Orang Tanpa } \\
\text { Gejala }\end{array}$ & Tinggi & $\begin{array}{l}\text { Penerapan social distancing dan physical } \\
\text { disctancing. } \\
\text { Melakukan kuota penerbangan setiap harinya. }\end{array}$ \\
\hline
\end{tabular}

(Sumber : Olah data, 2020) 
Tabel 5. Tindakan Yang Di Butuhkan

\begin{tabular}{|c|c|c|c|c|c|}
\hline No & $\begin{array}{l}\text { Guide } \\
\text { Word + } \\
\text { Parameter }\end{array}$ & Penyebab & Konsekuensi & Safeguard & $\begin{array}{c}\text { Tindakan yang } \\
\text { dibutuhkan }\end{array}$ \\
\hline 1. & $\begin{array}{l}\text { Tempat } \\
\text { duduk } \\
\text { dan meja } \\
\text { di ruang } \\
\text { tunggu }\end{array}$ & $\begin{array}{lr}\begin{array}{l}\text { Sering } \\
\text { memegang }\end{array} & \text { kursi } \\
\text { atau } & \text { meja } \\
\text { kemudian } & \\
\text { memegang } & \text { area } \\
\text { wajah } & \text { tanpa } \\
\text { mencuci tangan } & \\
\text { terlebih dahulu, } & \text { sedangkan virus } \\
\text { dapat } & \text { saja } \\
\text { menempel pada } & \text { kursi atau meja. } \\
\end{array}$ & $\begin{array}{l}\text { Virus dapat } \\
\text { menular pada } \\
\text { orang-orang } \\
\text { yang kontak } \\
\text { dengan kursi } \\
\text { dan meja }\end{array}$ & $\begin{array}{l}\text { Alat Pelindung } \\
\text { Diri seperti } \\
\text { sarung tangan }, \\
\text { masker atau face } \\
\text { shield serta } \\
\text { membawa Hand } \\
\text { Sanitizer }\end{array}$ & $\begin{array}{l}\text { Menyemprotkan } \\
\text { disinfektan pada } \\
\text { meja dan kursi, } \\
\text { Rajin mencuci } \\
\text { tangan dengan } \\
\text { sabun atau } \\
\text { menggunakan } \\
\text { handsanitizer dan } \\
\text { menggunakan } \\
\text { APD yang sesuai } \\
\text { dengan } \\
\text { semestinya }\end{array}$ \\
\hline 2. & $\begin{array}{l}\text { Kloset } \\
\text { duduk di } \\
\text { toilet }\end{array}$ & $\begin{array}{lr}\text { Virus } & \text { dapat } \\
\text { menempel } & \text { pada } \\
\text { kloset } & \text { toilet } \\
\text { duduk } & \end{array}$ & $\begin{array}{l}\text { Dapat terpapar } \\
\text { virus bagi } \\
\text { pengguna } \\
\text { kloset duduk }\end{array}$ & $\begin{array}{l}\text { Membawa hand } \\
\text { sanitizer }\end{array}$ & $\begin{array}{l}\text { Selalu } \\
\text { menyemprotkan } \\
\text { disinfektan pada } \\
\text { kloset duduk yang } \\
\text { akan digunakan, } \\
\text { serta mencuci } \\
\text { tangan dengan } \\
\text { sabun atau } \\
\text { menggunakan } \\
\text { hand sanitizer }\end{array}$ \\
\hline 3. & Eskalator & $\begin{array}{l}\text { Orang yang } \\
\text { menggunakan } \\
\text { escalator hampir } \\
\text { sebagaian selalu } \\
\text { memegang } \\
\text { pegangan } \\
\text { escalator dan } \\
\text { tangga nya yang } \\
\text { berdekatan } \\
\text { Karena kontak } \\
\text { langsung } \\
\text { otomatis virus } \\
\text { dapat menempel } \\
\text { pada pegangan } \\
\text { escalator. }\end{array}$ & $\begin{array}{l}\text { Virus dapat } \\
\text { menular pada } \\
\text { orang-orang } \\
\text { yang kontak } \\
\text { dengan } \\
\text { escalator. }\end{array}$ & $\begin{array}{l}\text { Alat Pelindung } \\
\text { Diri seperti } \\
\text { sarung tangan , } \\
\text { masker atau face } \\
\text { shield serta } \\
\text { membawa Hand } \\
\text { Sanitizer }\end{array}$ & $\begin{array}{l}\text { Menyemprotkan } \\
\text { disinfektan pada } \\
\text { escalator secara } \\
\text { berkala, Rajin } \\
\text { mencuci tangan } \\
\text { dengan sabun atau } \\
\text { menggunakan } \\
\text { handsanitizer. }\end{array}$ \\
\hline 4. & Troli. & $\begin{array}{ll}\text { Orang } & \text { yang } \\
\text { menggunakan } \\
\text { troli dan virus } \\
\text { dapat menempel } \\
\text { pada pegangan } \\
\text { troli. }\end{array}$ & $\begin{array}{l}\text { Virus dapat } \\
\text { menular pada } \\
\text { orang-orang } \\
\text { yang kontak } \\
\text { dengan troli } \\
\text { (menggunakan } \\
\text { troli). }\end{array}$ & $\begin{array}{l}\text { Alat Pelindung } \\
\text { Diri seperti } \\
\text { sarung tangan }, \\
\text { membawa Hand } \\
\text { Sanitizer }\end{array}$ & $\begin{array}{l}\text { Menyemprotkan } \\
\text { disinfektan pada } \\
\text { troli secara } \\
\text { berkala, Rajin } \\
\text { mencuci tangan } \\
\text { dengan sabun atau } \\
\text { menggunakan } \\
\text { handsanitizer }\end{array}$ \\
\hline
\end{tabular}




\begin{tabular}{|c|c|c|c|c|c|}
\hline 5. & Uang & $\begin{array}{lr}\text { Terjadi } & \text { kontak } \\
\text { langsung antara } \\
\text { konsumen dan } \\
\text { kasir pada saat } \\
\text { pembelian } \\
\text { makanan/tiket. }\end{array}$ & $\begin{array}{l}\text { Virus dapat } \\
\text { menular pada } \\
\text { orang-orang } \\
\text { yang kontak } \\
\text { dengan uang, } \\
\text { karena virus } \\
\text { dapat } \\
\text { menempel } \\
\text { pada uang. }\end{array}$ & $\begin{array}{l}\text { Alat Pelindung } \\
\text { Diri seperti } \\
\text { sarung tangan } \\
\text {,menggunakan } \\
\text { Hand Sanitizer } \\
\text { setelah } \\
\text { pembayaran }\end{array}$ & $\begin{array}{l}\text {-Untuk } \\
\text { pembayaran } \\
\text { sebaiknya } \\
\text { menggunkan } \\
\text { system } \\
\text { online/card/e- } \\
\text { money/uang } \\
\text { digital } \\
\text { (DANA/OVO). }\end{array}$ \\
\hline 6. & $\begin{array}{l}\text { Tangga } \\
\text { Pesawat }\end{array}$ & $\begin{array}{l}\text { Orang yang akan } \\
\text { naik ke pesawat } \\
\text { akan kontak } \\
\text { langsung dengan } \\
\text { pegangan tangga } \\
\text { pada pesawat. }\end{array}$ & $\begin{array}{l}\text { Virus dapat } \\
\text { menempel } \\
\text { pada } \\
\text { pegangan } \\
\text { karena adanya } \\
\text { kontak } \\
\text { langsung. }\end{array}$ & $\begin{array}{l}\text { Alat Pelindung } \\
\text { Diri seperti } \\
\text { sarung tangan } \\
\text {,menggunakan } \\
\text { Hand Sanitizer } \\
\text { setelah naik ke } \\
\text { pesawat. }\end{array}$ & $\begin{array}{l}\text { Di dalam pesawat } \\
\text { disediakan } \\
\text { handsanitizer. }\end{array}$ \\
\hline
\end{tabular}

(Sumber : Olah data, 2020)

Dari tindakan yang dibutuhkan tersebut, salah satu penerapan dibandara yang terlihat dari sudut pandang peneliti sebagai berikut :

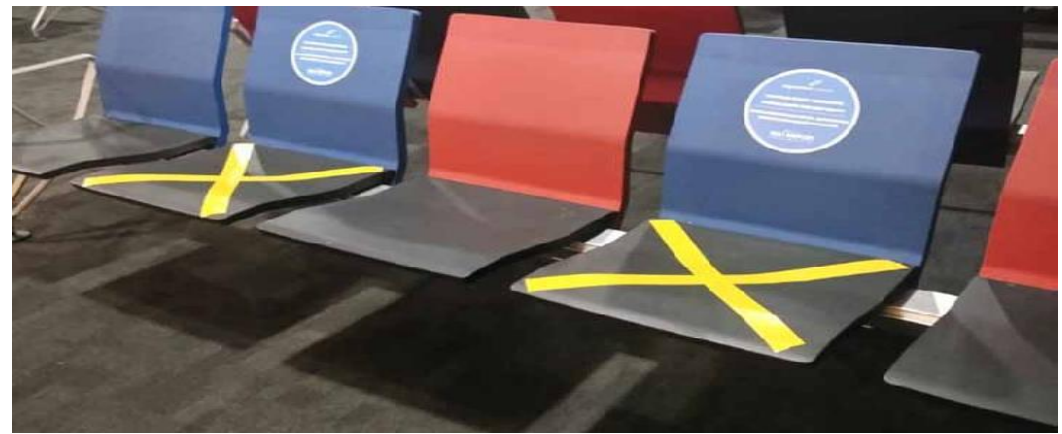

Gambar 4. Antisipasi Penyebaran Covid-19 di Ruang Tunggu Bandara

Antisipasi penyebaran COVID-19 di bandara adalah antara lain dengan memberikan jarak duduk penumpang pada kursi ruang tunggu di bandara saat menunggu masuk ke dalam pesawat. Dengan cara ini, penumpang yang sudah terinfeksi virus maupun penumpang yang sehat tidak akan berkontak langsung atau bersentuhan, sehingga penyebaran virus pun dapat dicegah.

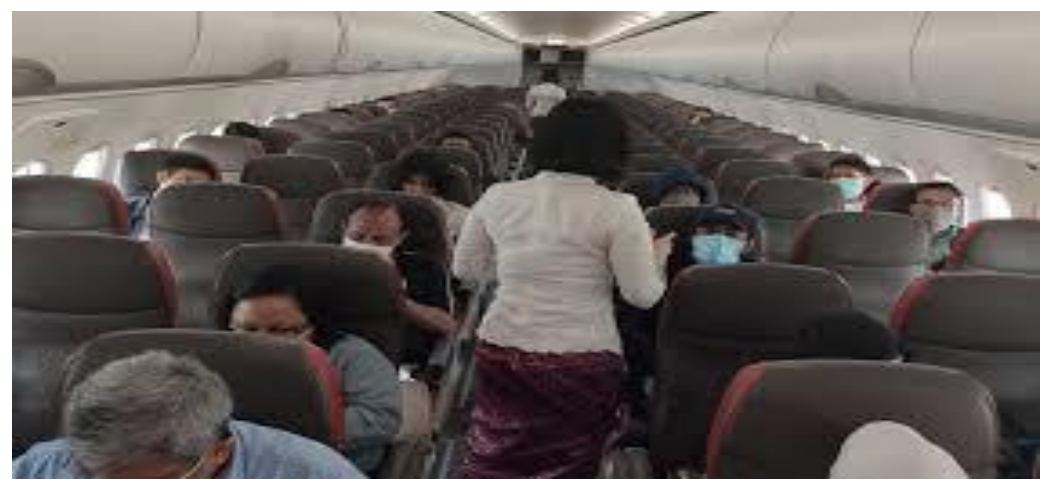

Gambar 5. Antisipasi Penyebaran COVID-19 Pada Kursi Penumpang di dalam Pesawat 
Pada gambar tersebut dapat kita lihat penumpang yang berada dalam pesawat tidak duduk bersebelahan seperti biasanya, melainkan diberikan jeda satu kursi kosong dari satu penumpang ke penumpang yang lain. Penumpang yang berada di dalam pesawat pun harus memakai masker. Hal ini merupakan salah satu antisipasi yang dilakukan dari pihak bandara untuk mencegah terjadinya penyebaran covid-19.

\section{Kesimpulan dan Saran}

Kesimpulan yang dapat diambil dari penelitian ini berdasarkan rumusan masalah adalah sebagai berikut:

1. Potensi bahaya kecelakaan kerja yang dapat terjadi pada puskesmas berasal dari sumber bahaya yang telah digolongkan 12 sumber.

2. Risiko bahaya yang ditimbulkan pada bandara meliputi resiko ekstrim, risiko tinggi, dan risiko sedang.

3. Rekomendasi yang diberikan kepada bandara berdasarkan sumber bahaya yang ada, meliputi sikap pekerja, management bandara dan pemerintah. Untuk menyikapi sikap pekerja, harus dibuat prosedur operasional baku untuk keselamatan dan kesehatan kerja (K3). Untuk memperbaiki management di bandara, harus dilakukan perbaikan sesuai kondisi yang dihadapi. Untuk pemerintah harus dilakukan evaluasi dari penularan covid-19 jika masih terus ada yang berpergian ke luar negeri atau turis asing yang berdatangan.

\section{Daftar Pustaka}

[1] T. M. Abd El-Aziz and J. D. Stockand, "Recent progress and challenges in drug development against COVID-19 coronavirus (SARS-CoV-2) - an update on the status," Infect. Genet. Evol., vol. 83, no. April, p. 104327, 2020.

[2] M. A. Shereen, S. Khan, A. Kazmi, N. Bashir, and R. Siddique, "COVID-19 infection: Origin, transmission, and characteristics of human coronaviruses," J. Adv. Res., vol. 24, pp. 91-98, 2020.

[3] D. Kaul, "An overview of coronaviruses including the SARS-2 coronavirus Molecular biology, epidemiology and clinical implications," Curr. Med. Res. Pract., vol. 10, no. 2, pp. 54-64, 2020.

[4] L. Bai et al., "Chinese experts' consensus on the Internet of Things-aided diagnosis and treatment of coronavirus disease 2019 (COVID-19)," Clin. eHealth, vol. 3, pp. $7-15,2020$.

[5] A. R. A. H. Hamid, "Social responsibility of medical journal: A concern for covid19 pandemic," Med. J. Indones., vol. 29, no. 1, pp. 1-3, 2020.

[6] F. E. B. Setyawan and R. Lestari, "Challenges of Stay-At-Home Policy Implementation During the Coronavirus (Covid-19) Pandemic in Indonesia," $J$. Adm. Kesehat. Indones., vol. 8, no. 2, p. 15, 2020.

[7] Y.-C. Wu, C.-S. Chen, and Y.-J. Chan, "The outbreak of COVID-19: An overview," J. Chinese Med. Assoc., vol. 83, no. 3, 2020.

[8] F. Freudenstein, R. J. Croft, P. M. Wiedemann, A. Verrender, C. Böhmert, and S. P. Loughran, "Framing effects in risk communication messages - Hazard 
identification vs. risk assessment," Environ. Res., vol. 190, p. 109934, 2020.

[9] R. Pawin vivid, N. Selvakumar, and M. Ruvankumar, "Determination of hazard in truck manufacturing industry using hazard identification risk assessment technique," Mater. Today Proc., vol. 27, pp. 1858-1862, 2020.

[10] E. D. Wickham et al., "Conducting a drought-specific THIRA (Threat and Hazard Identification and Risk Assessment): A powerful tool for integrating all-hazard mitigation and drought planning efforts to increase drought mitigation quality," Int. J. Disaster Risk Reduct., vol. 39, p. 101227, 2019.

[11] N. Chartres, L. A. Bero, and S. L. Norris, "A review of methods used for hazard identification and risk assessment of environmental hazards," Environ. Int., vol. 123, no. December 2018, pp. 231-239, 2019.

[12] Z. Wang, W. C. Scott, E. S. Williams, M. Ciarlo, P. C. DeLeo, and B. W. Brooks, "Identification of novel uncertainty factors and thresholds of toxicological concern for health hazard and risk assessment: Application to cleaning product ingredients," Environ. Int., vol. 113, pp. 357-376, 2018.

[13] A. Garcia-Aristizabal, P. Capuano, R. Russo, and P. Gasparini, "Multi-hazard risk pathway scenarios associated with unconventional gas development: Identification and challenges for their assessment," Energy Procedia, vol. 125, pp. 116-125, 2017.

[14] A. Ogunlaja, O. O. Ogunlaja, D. M. Okewole, and O. A. Morenikeji, "Risk assessment and source identification of heavy metal contamination by multivariate and hazard index analyses of a pipeline vandalised area in Lagos State, Nigeria," Sci. Total Environ., vol. 651, pp. 2943-2952, 2019.

[15] S. Scholz et al., "A European perspective on alternatives to animal testing for environmental hazard identification and risk assessment," Regul. Toxicol. Pharmacol., vol. 67, no. 3, pp. 506-530, 2013.

[16] O. E. Williamson et al., "CAPACIDADES DINÂMICAS COMO DIFERENCIAL ESTRATÉGICO PARA A SUSTENTABILIDADE,” J. Bus. Res., 2016.

[17] P. Singh, A. Kaur, and A. K. Gupta, "Hazard-risk and vulnerability assessment for the National Zoological Park at New Delhi, India," Int. J. Disaster Risk Reduct., vol. 50, p. 101819, 2020.

[18] J. Nakayama, J. Sakamoto, N. Kasai, T. Shibutani, and A. Miyake, "Preliminary hazard identification for qualitative risk assessment on a hybrid gasoline-hydrogen fueling station with an on-site hydrogen production system using organic chemical hydride," Int. J. Hydrogen Energy, vol. 41, no. 18, pp. 7518-7525, 2016.

[19] Sunaryo and M. A. Hamka, "Safety risks assessment on container terminal using hazard identification and risk assessment and fault tree analysis methods," Procedia Eng., vol. 194, pp. 307-314, 2017.

[20] H. Hadef, B. Negrou, T. G. Ayuso, M. Djebabra, and M. Ramadan, "Preliminary hazard identification for risk assessment on a complex system for hydrogen production," Int. J. Hydrogen Energy, vol. 45, no. 20, pp. 11855-11865, 2020.

[21] E. de Freitas Costa, M. Cardoso, J. D. Kich, and L. G. Corbellini, “A qualitative risk assessment approach to microbial foodborne hazards in Brazilian intensive pork 
production: A step towards risk prioritization," Microb. Risk Anal., vol. 15, p. $100105,2020$.

[22] S. Gahayu, "Metodologi Penelitian Kesehatan," Deepublish, 2015.

[23] Suryabrata, Metodologi Penelitian. 2014.

[24] M. A. Kamrin, "Hazard Identification," in Encyclopedia of Toxicology: Third Edition, 2014. 